\title{
Influence of Winemaking Procedure and Grape Variety on the Colour and Composition of Young Red Wines
}

\author{
G. González-Neves ${ }^{1, *}$, G. Gil ${ }^{2}$, G. Favre ${ }^{1}$, C. Baldi ${ }^{1}$, N. Hernández ${ }^{1}$, S. Traverso $^{1}$ \\ (1) Facultad de Agronomía, Universidad de la República, Avda. Garzón 780, C.P. 12900, Montevideo, Uruguay \\ (2) Instituto Nacional de Vitivinicultura, Dr. Pouey 463, C.P. 90200, Las Piedras, Uruguay
}

Submitted for publication: February 2013

Accepted for publication: March 2013

Key words: Anthocyanins, polyphenols, colour of wines, Tannat

\begin{abstract}
The influence of winemaking procedure and grape variety on the colour and composition of young red wines was evaluated. For this purpose, Tannat, Syrah and Merlot wines were elaborated in Uruguay in 2011. Traditional maceration (TM), the addition of pectolytic enzymes (ENZ) and cold pre-fermentative maceration before traditional maceration (CPM) were the alternative procedures of winemaking tested. Two batches of grapes $(70 \mathrm{~kg}$ each) were employed for each winemaking procedure. Tannat wines had the highest colour intensity, red colour $\left(\mathrm{a}^{*}\right)$, and anthocyanin, proanthocyanidin and alcohol content, and the lowest luminosity $\left(\mathrm{L}^{*}\right)$ and $\mathrm{pH}$ values. CPM increased the colour intensity and total polyphenol, anthocyanin and proanthocyanidin content in Tannat and Merlot wines. Pectolytic additions enhanced colour intensity and red colour and decreased the luminosity in all wines. Meanwhile, enzyme additions enhanced proanthocyanidin content in all cases. Pectolytic enzyme significantly increased the methanol levels of the wines. Nevertheless, the amounts of this compound are far within maximum acceptable limits. Principal component analysis of the data shows significant separation between the wines of each variety, since the colour and composition are largely related to the cultivar and the vintage, despite the effect of the winemaking procedures.
\end{abstract}

\section{INTRODUCTION}

The traditional winemaking process of red wines consists of skin contact during the alcoholic fermentation of must. The grape composition and the winemaking practices determine the composition and sensorial properties of young red wines. Grape composition depends on environmental factors, vineyard management practices and grape variety. The sensorial properties of young red wines, such as colour, flavour and mouthfeel, depend on several components extracted from grapes, among which stand out many polyphenols. Anthocyanins and their derivatives are the pigments of young red wines. Tannins (proanthocyanidins) participate in astringency, bitterness and the colour of wines. Anthocyanins and tannins are extracted together with others polyphenols from red grapes to musts during the maceration process. The length of time of skin contact, the concentration of ethanol and the temperature of musts are the most important factors that modify the diffusion of anthocyanins and tannins from pomace and their solubilisation into the must (Canals et al., 2005; Sacchi et al., 2005).

Many winemaking procedures have been proposed as alternative to the traditional elaboration of red wines, considering the selective effect of the maceration conditions on the extraction of the different grape components and the reactions in which they participate (Sacchi et al., 2005). Two oenological practices used for this purpose are cold pre-fermentative maceration and the addition of macerating enzymes, which have been proposed for enhancing the release of polyphenols from grapes, stabilising the colour, and favouring the formation of new pigments (BautistaOrtín et al., 2005; Sacchi et al., 2005; Álvarez et al., 2006; Gómez-Míguez et al., 2007; Bautista-Ortín et al., 2012; Ortega-Heras et al., 2012).

Cold pre-fermentative maceration is employed to favour the extraction of compounds from skins in aqueous medium. This situation promotes the preferential solubility of the water-soluble compounds, thus enhances the release of anthocyanins and tannins of low molecular weight. In contrast, high-weight tannins are more soluble in alcoholic solutions, so their extraction depends on the completion of alcoholic fermentation (Sacchi et al., 2005; Álvarez et al., 2006).

Several papers have presented contradictory results relating to the use of this technique in the vinification of grapes of different varieties (Parenti et al., 2004; Sacchi et al., 2005; Álvarez et al., 2006, De Beer et al., 2006; Gómez-

*Corresponding author: E-mail: gustavogn@fagro.edu.uy

Aknowledgements: The authors are grateful to F. Abonna, J. Balado, V. Berriel, R. Bochicchio, D. Charamelo, E. Delgado, L. Duter, G. Gatto, M. Garcia, F. Matteo, I. Riccetto and A. Tessore, for their participation in this work. The authors acknowledge the financial support of Project CSIC-Udelar I+D 2010 and Project PR-FMV-2009-1-2622 
Míguez et al., 2007; Álvarez et al., 2009; Gil-Muñoz et al., 2009; González-Neves et al., 2009; Heredia et al., 2010; Busse-Valverde et al., 2011; González-Neves et al., 2012).

Moreover, the use of commercial macerating enzymes in winemaking is a common and well-known practice. These preparations degrade the structural polysaccharides of grape skin cell walls, facilitating the release of phenolic compounds. The enzymes used in oenology are pectinase preparations (which mainly contain polygalacturonase, pectin esterase and pectin lyase activities), with the addition of small amounts of cellulase and hemicellulase in order to achieve a more complete breakdown of the cells and to enhance colour extraction (Romero-Cascales et al., 2012).

There are many studies that have reported an improvement in the colour of wines with these preparations (Bautista-Ortín et al., 2005; Ortega-Heras et al., 2012; Romero-Cascales et al., 2012; Bautista-Ortín et al., 2012), although some authors have reported the opposite (Revilla \& González-Sanjosé, 2001). Macerating enzymes may modify the stability, taste and structure of red wines, because not only the anthocyanins are released from skins, but also tannins bound to the skin cell walls and those located in seed cells (Bautista-Ortin et al., 2012). The effect of the enzymatic preparations is also conditioned by the structure and composition of the skin cell walls. This effect therefore can be very different, depending on the grape variety, because genetic factors regulate these features (Ortega-Regules et al., 2008).

The aim of this work was to evaluate the behaviour of some winemaking alternatives in three grape varieties and their effect on the composition of young red wines. For this purpose, wines were produced with Tannat, Syrah and Merlot in Uruguay in 2011, using alternative procedures of winemaking. Traditional maceration (TM), the addition of pectolytic enzymes (ENZ) and cold pre-fermentative maceration before traditional maceration (CPM) were the winemaking procedures tested.

Tannat, Merlot and Syrah are important red varieties in Uruguay. Tannat (Vitis vinifera L.) is the main red variety cultivated in the country since the middle of nineteenth century. This cultivar is well adapted to the ecological conditions of the country, producing wines with outstanding qualities, especially great typicality and originality. The effects of the application of alternative winemaking techniques on the composition of these wines have been reported in a few research papers (González-Neves et al., 2009, 2010, 2012).

\section{MATERIALS AND METHODS \\ Grapes}

The assays were carried out in the 2011 vintage. Merlot, Syrah and Tannat grapes were grown in the south of Uruguay and were harvested according to their sugar contents, total acidity and $\mathrm{pH}$. For this purpose, samples of grapes in each vineyard were collected weekly and analysed according to the methods in O.I.V. (2012). Duplicate samples were collected for the analysis of the phenolic potential of the grapes according to Glories and Augustin (1993).

The analyses were carried out using an Atago N1 refractometer (Atago, Japan), a Hanna HI8521 pH meter
(Hanna instruments, Italy), and a Shimadzu UV-1240 Mini spectrophotometer (Shimadzu, Japan). At harvest, the clusters were transported to the winery in plastic boxes (20 $\mathrm{kg}$ each).

\section{Winemaking}

Two batches of grapes (70 kg each) were used in each winemaking procedure. Grapes were destemmed and crushed with an Alfa 60 R crusher (Italcom, Italy), and the barrelling was done in stainless steel tanks (100 L capacity each). Traditional maceration (TM), the addition of pectolytic enzymes (ENZ), and cold pre-fermentative maceration before traditional maceration (CPM) were the winemaking techniques compared in each variety. TM was employed as the control treatment.

Potassium metabisulphite (50 mg $\mathrm{SO}_{2} / 100 \mathrm{~kg}$ of grapes) was added and all the musts were inoculated with dry active yeast (20 g/HL Saccharomyces cerevisiae Natuferm 804; OenoBioTech, France). The sulphur dioxide additions were done immediately after the crushing of the grapes. The yeast inoculations were added immediately in the TM and ENZ musts, while they were added after the pre-fermentative process in CPM.

The control wines (TM) were made by classical fermentation on skins for seven days in the case of Merlot and Syrah and eight days for Tannat, according to the polyphenolic potential of the grapes (Table 1). The wines were pumped over twice daily, followed by punching down the cap, along with the skin contact. The temperature of fermentation was between 23 and $26^{\circ} \mathrm{C}$ in Tannat, and between 25 and $29^{\circ} \mathrm{C}$ in Merlot and Syrah.

The CPM wines were elaborated with skin contact at low temperature $\left(10\right.$ to $\left.15^{\circ} \mathrm{C}\right)$ for five days before fermentation, cooling the must with cold exchangers (frozen water containers). After that, a classical fermentation with skin contact was carried out for five days at the same temperature as the control wines.

ENZ wines were produced with the addition of commercial pectolytic enzymes $(2.5 \mathrm{~g} / 100 \mathrm{~kg}$ grapes, Rapidase Ex Color; DSM, The Netherlands), following the destemming and crushing of the grapes. Classical fermentation on the skins was carried out for seven days in the case of Merlot and Syrah, and for eight days with Tannat, according to the control wines.

At devatting, free-run juice was obtained and the marc was pressed with a stainless steel manual press. In all cases, free-run juices and press juices were mixed. The wines were kept in the stainless steel tanks, where the fermentations were completed, until racking. At the end of alcoholic fermentation, dioxide additions $(50 \mathrm{mg} \mathrm{SO} / \mathrm{L})$ were made to inhibit malolactic fermentation. Finally, the wines were kept in glass containers with a capacity of 10 litres, closed with cork stoppers, until analysis.

\section{Wine analyses}

The wines were analysed four months after vinification. Two replications of the analyses were performed in all cases. The base composition (level of alcohol, total acidity, volatile acidity, residual sugars, total sulphur dioxide, and $\mathrm{pH}$ ) was determined according to classical oenological methods 
TABLE 1

Composition of grapes.

\begin{tabular}{lcccccccc}
\hline Variety & $\mathrm{S}$ & $\mathrm{TA}$ & $\mathrm{pH}$ & $\mathrm{A} 280$ & $\mathrm{ApH} 1$ & $\mathrm{ApH} .2$ & $\mathrm{EA} \%$ & $\mathrm{Mp} \%$ \\
\hline Merlot & $221.5 \mathrm{~b} \pm 1.9$ & $3.0 \mathrm{~b} \pm 0.1$ & $3.57 \mathrm{a} \pm 0.05$ & $42.5 \mathrm{~b} \pm 0.2$ & $972 \mathrm{c} \pm 27$ & $568 \mathrm{~b} \pm 6$ & $41.6 \mathrm{c} \pm 1.1$ & $46.5 \mathrm{a} \pm 0.8$ \\
Syrah & $198.2 \mathrm{c} \pm 2.1$ & $3.9 \mathrm{a} \pm 0.1$ & $3.33 \mathrm{~b} \pm 0.01$ & $33.2 \mathrm{c} \pm 0.1$ & $1175 \mathrm{~b} \pm 23$ & $511 \mathrm{c} \pm 10$ & $56.5 \mathrm{a} \pm 0.1$ & $38.4 \mathrm{~b} \pm 1.2$ \\
Tannat & $240.0 \mathrm{a} \pm 2.3$ & $4.1 \mathrm{a} \pm 0.1$ & $3.30 \mathrm{~b} \pm 0.02$ & $75.5 \mathrm{a} \pm 2.5$ & $1583 \mathrm{a} \pm 57$ & $832 \mathrm{a} \pm 16$ & $47.5 \mathrm{~b} \pm 0.9$ & $33.3 \mathrm{c} \pm 1.0$ \\
\hline
\end{tabular}

Mean values \pm standard deviations. Values with the same letter in the same column have no statistical significant differences according to a Tukey test $(\mathrm{p}<0.05)$. S: sugar content, in $\mathrm{mg} / \mathrm{L}$; TA: total acidity, in $\mathrm{mg} / \mathrm{L}$; A280: phenolic richness, in absorbance units (AU); ApH1: total anthocyanin potential, in $\mathrm{mg} / \mathrm{L}$ of malvidin glucoside; ApH3.2: extractable anthocyanin potential, in $\mathrm{mg} / \mathrm{L}$ of malvidin glucoside; EA\%: extractability of anthocyanins; $\mathrm{Mp} \%$ : proportion of seed tannins.

(O.I.V., 2012). Total polyphenols and proanthocyanidin contents were determined by spectrophotometric methods. Total polyphenols were analysed with Folin-Ciocalteu reagent, according to Singleton and Rossi (1965). The proanthocyanidin content of the wines was measured according to the method proposed by Ribéreau-Gayon and Stonestreet (1966). The DMACH index was measured according to Vivas et al. (1994). The tannin polymerisation index was calculated as the relationship between the DMACH index and the proanthocyanidin content.

The colour of the wines was evaluated with the indexes proposed by Glories (1984): colour intensity (CI), hue, and yellow $(\mathrm{Y} \%)$, red $(\mathrm{R} \%)$ and blue $(\mathrm{B} \%)$ percentages. Also, the CIELAB parameters brightness $\left(\mathrm{L}^{*}\right)$, chromaticity $\left(\mathrm{C}^{*}\right)$, redness $\left(a^{*}\right)$ and yellowness $\left(b^{*}\right)$ were determined, using the D65 illuminant and a $10^{\circ}$ observer according to Ayala et al. (1997). Co-pigmentation indexes according to Boulton (2001) were measured and colour due to anthocyanins (A), colour due to co-pigmentation (C) and colour due to polymers $(\mathrm{P})$ were calculated.

The wines were centrifuged for $3 \mathrm{~min}$ at $3000 \mathrm{rpm}$ before spectrophotometric analysis. The measurements were carried out using a Cole Parmer S2100-UV+ (Cole Parmer, USA) and a Shimadzu UV-1800 (Shimadzu, Japan) UV-VIS spectrophotometer, employing glass cells with a $1 \mathrm{~mm}$ path length for the colour analyses and glass cells with a $1 \mathrm{~cm}$ path length for the polyphenol analyses.

The anthocyanin content of the wines was determined by HPLC-DAD, according to Revilla et al. (1999). Briefly, after filtration through Sartorius filters (Sartorius, USA) $(0.45 \mu \mathrm{m}$ diameter), the samples were injected directly into a chromatographic system equipped with two pumps - Waters 510 and 515, a Rheodyne $7725 \mathrm{i}$ injector ( $20 \mu \mathrm{m}$ loop) and a photodiode detector Waters 2996 (Waters Corp., USA). The system was controlled with Millennium 32 Software (Waters Corp., USA). A Luna C18 reverse phase column, $5 \mu \mathrm{m}, 150$ $\mathrm{x}$ 4,6 $\mathrm{mm}$ (Phenomenex, USA) was used as the stationary phase, with a mobile phase flow rate of $0.8 \mathrm{~mL} / \mathrm{min}$. The solvent A was an aqueous solution (10\%) of formic acid, and solvent B was an aqueous solution of methanol (45\%) and formic acid (10\%). The gradient established was: from 35 to $95 \%$ B for $20 \mathrm{~min}$, from 95 to $100 \%$ B for $5 \mathrm{~min}$, isocratic $100 \%$ B for 5 min (Revilla et al., 1999).

The identification of the compounds was carried out taking into account the spectrum of each and the retention time of each peak. Previously, the identification was confirmed (González-Neves et al., 2010) using a chromatographic system with a mass spectrophotometer (Hewlett Packard
1100 Series LC-MS) as a reference. The concentration of each pigment was calculated using a calibration curve with malvidin glucoside chloride. The total anthocyanin content of the wines was calculated considering the sum of all the anthocyanins quantified.

Analyses of the major volatile compounds (higher alcohols, methanol and ethyl acetate) were performed by distillation of $100 \mathrm{~mL}$ of sample and direct injection of 1.0 $\mu \mathrm{L}$ of sample of the distillate into a GC-FID system. The analyses were carried out using an HP-INNOWAX HP$19091 \mathrm{~N}-133$ bonded fused silica capillary column $(30 \mathrm{~m}$ x $0.25 \mathrm{~mm}$ i.d.) coated with polyethylene glycol $(0.25 \mu \mathrm{m}$ phase thickness) and a Agilent $6890 \mathrm{~N}$ gas chromatograph with a flame ionisation detector (Agilent Tech., USA). The column temperature varied from $35^{\circ} \mathrm{C}(3 \mathrm{~min})$ to $165^{\circ} \mathrm{C}$ at $8^{\circ} \mathrm{C} / \mathrm{min}$. The following additional parameters were used: injector temperature, $220^{\circ} \mathrm{C}$; injection mode was splitless; volume injected was $1 \mu \mathrm{L}$; carrier gas was hydrogen. Identification was carried out by comparison of the retention times with those of corresponding pure standards, and quantification was based on the calibration curves of the respective standards. A sample of $50 \mathrm{~mL}$ of distilled wine with $5 \mathrm{~mL}$ of internal standard (4-methyl-2-pentanol) was used for each analysis.

\section{Statistical analyses}

Analyses of variance and media separation by Tukey at 5\% were performed using the Statgraphics Plus package, version 4.1 (Statgraphics Corp., USA).

Principal component analysis (PCA) of data from the colour indexes, and the basic, volatile and phenolic composition of the wines, were performed using Statgraphics Centurion XVI V. 16.1.18 (Stat Point Tech., USA).

\section{RESULTS AND DISCUSSION}

The composition of the grapes of the three varieties is shown in Table 1. The grapes of Tannat had the highest richness in sugars, polyphenols and anthocyanins. Merlot grapes had the lowest acidity and the highest $\mathrm{pH}$ values, which influenced the acidity and the colour of the wines of this variety. Syrah grapes had the highest values of EA\%, showing a low extractability of anthocyanins.

Several properties of the wine depend strongly on the composition of the grapes of origin. Consequently, the alcohol content, total acidity, colour and polyphenolic composition of the wines of the three varieties were very different (Tables 2 to 4; Fig. 1). These results are related to the different grade of ripeness of the grapes of the three 
TABLE 2

General composition of wines.

\begin{tabular}{cccccccc}
\hline Variety & Winemaking & Alcohol & Total acidity & $\begin{array}{c}\text { Volatile } \\
\text { acidity }\end{array}$ & $\mathrm{pH}$ & $\begin{array}{c}\text { Residual } \\
\text { sugars }\end{array}$ & $\begin{array}{c}\text { Total sulphur } \\
\text { dioxide }\end{array}$ \\
\hline \multirow{3}{*}{ Merlot } & TM & $12.6 \mathrm{~ns} \pm 0.1$ & $69.8 \mathrm{~b} \pm 2.0$ & $4.3 \mathrm{~ns} \pm 0.6$ & $3.55 \mathrm{a} \pm 0.01$ & $2.0 \mathrm{~b} \pm 0.1$ & $48.7 \mathrm{~b} \pm 0.6$ \\
& ENZ & $12.6 \mathrm{~ns} \pm 0.1$ & $78.1 \mathrm{a} \pm 0.4$ & $4.1 \mathrm{~ns} \pm 0.2$ & $3.46 \mathrm{c} \pm 0.01$ & $2.4 \mathrm{a} \pm 0.1$ & $67.2 \mathrm{a} \pm 2.6$ \\
& CPM & $12.5 \mathrm{~ns} \pm 0.1$ & $3.90 \mathrm{a} \pm 1.0$ & $4.3 \mathrm{~ns} \pm 0.4$ & $3.49 \mathrm{~b} \pm 0.01$ & $2.0 \mathrm{~b} \pm 0.1$ & $45.4 \mathrm{~ns} \pm 2.4$ \\
\hline \multirow{3}{*}{ Syrah } & TM & $11.6 \mathrm{~ns} \pm 0.3$ & $65.9 \mathrm{c} \pm 1.8$ & $5.9 \mathrm{~ns} \pm 0.2$ & $3.40 \mathrm{a} \pm 0.01$ & $2.3 \mathrm{~b} \pm 0.1$ & $43.9 \mathrm{~ns} \pm 4.4$ \\
& ENZ & $11.6 \mathrm{~ns} \pm 0.1$ & $75.1 \mathrm{a} \pm 0.8$ & $6.3 \mathrm{~ns} \pm 0.6$ & $3.32 \mathrm{c} \pm 0.02$ & $2.7 \mathrm{a} \pm 0.1$ & $42.1 \mathrm{~ns} \pm 5.2$ \\
& CPM & $11.6 \mathrm{~ns} \pm 0.1$ & $68.1 \mathrm{~b} \pm 0.4$ & $5.5 \mathrm{~ns} \pm 0.6$ & $3.37 \mathrm{~b} \pm 0.01$ & $2.2 \mathrm{~b} \pm 0.2$ & $44.8 \mathrm{~ns} \pm 7.9$ \\
\hline \multirow{3}{*}{ Tannat } & TM & $14.8 \mathrm{ab} \pm 0.1$ & $90.8 \mathrm{~b} \pm 0.2$ & $6.3 \mathrm{~b} \pm 0.2$ & $3.31 \mathrm{~ns} \pm 0.03$ & $2.1 \mathrm{~b} \pm 0.1$ & $54.4 \mathrm{~ns} \pm 0.1$ \\
& ENZ & $14.6 \mathrm{~b} \pm 0.2$ & $93.8 \mathrm{a} \pm 1.2$ & $5.7 \mathrm{~b} \pm 0.2$ & $3.29 \mathrm{~ns} \pm 0.01$ & $2.3 \mathrm{ab} \pm 0.1$ & $49.5 \mathrm{~ns} \pm 5.4$ \\
& CPM & $14.9 \mathrm{a} \pm 0.1$ & $90.2 \mathrm{~b} \pm 1.4$ & $8.4 \mathrm{a} \pm 1.4$ & $3.30 \mathrm{~ns} \pm 0.01$ & $2.4 \mathrm{a} \pm 0.2$ & $37.1 \mathrm{~ns} \pm 0.1$ \\
\hline
\end{tabular}

Mean values \pm standard deviations. Values with the same letter in the same column and in the same variety mean that there are no statistically significant differences according to a Tukey test $(\mathrm{p}<0.05)$. Alcohol contents are expressed in ethanol \% v/v; Total and volatile acidity in meq/L; Residual sugars in glucose g/L; Total sulphur dioxide in mg/L.

TABLE 3

Colour indexes of the wines.

\begin{tabular}{cccccccc}
\hline Variety & Winemaking & CI & Hue & $\mathrm{L}^{*}$ & $\mathrm{C}^{*}$ & $\mathrm{a}^{*}$ & $\mathrm{~b}^{*}$ \\
\hline \multirow{3}{*}{ Merlot } & TM & $7.94 \mathrm{c} \pm 0.19$ & $0.52 \mathrm{~ns} \pm 0.01$ & $60.7 \mathrm{a} \pm 0.6$ & $46.6 \mathrm{~b} \pm 0.6$ & $46.4 \mathrm{~b} \pm 0.6$ & $4.1 \mathrm{~ns} \pm 1.1$ \\
& ENZ & $8.97 \mathrm{~b} \pm 0.08$ & $0.50 \mathrm{~ns} \pm 0.01$ & $57.3 \mathrm{~b} \pm 0.4$ & $50.7 \mathrm{a} \pm 0.6$ & $50.4 \mathrm{a} \pm 0.7$ & $5.5 \mathrm{~ns} \pm 0.4$ \\
& CPM & $9.59 \mathrm{a} \pm 0.26$ & $0.52 \mathrm{~ns} \pm 0.02$ & $55.5 \mathrm{c} \pm 0.8$ & $51.2 \mathrm{a} \pm 1.3$ & $50.9 \mathrm{a} \pm 1.3$ & $5.5 \mathrm{~ns} \pm 0.8$ \\
\hline \multirow{3}{*}{ Syrah } & TM & $5.48 \mathrm{~ns} \pm 0.94$ & $0.58 \mathrm{a} \pm 0.01$ & $68.8 \mathrm{~ns} \pm 4.2$ & $34.4 \mathrm{~b} \pm 3.4$ & $34.3 \mathrm{~b} \pm 3.4$ & $-2.8 \mathrm{~b} \pm 0.2$ \\
& ENZ & $6.52 \mathrm{~ns} \pm 0.60$ & $0.57 \mathrm{ab} \pm 0.02$ & $64.5 \mathrm{~ns} \pm 2.5$ & $40.1 \mathrm{a} \pm 2.9$ & $40.1 \mathrm{a} \pm 2.9$ & $-1.0 \mathrm{a} \pm 0.4$ \\
& CPM & $5.47 \mathrm{~ns} \pm 0.11$ & $0.54 \mathrm{~b} \pm 0.02$ & $68.3 \mathrm{~ns} \pm 0.5$ & $37.8 \mathrm{ab} \pm 0.2$ & $37.7 \mathrm{ab} \pm 0.2$ & $-3.5 \mathrm{c} \pm 0.1$ \\
\hline \multirow{3}{*}{ Tannat } & TM & $13.65 \mathrm{~b} \pm 0.62$ & $0.51 \mathrm{a} \pm 0.01$ & $43.5 \mathrm{a} \pm 1.0$ & $57.4 \mathrm{~b} \pm 2.1$ & $57.0 \mathrm{~b} \pm 1.8$ & $6.0 \mathrm{~ns} \pm 3.5$ \\
& ENZ & $15.18 \mathrm{a} \pm 0.75$ & $0.47 \mathrm{~b} \pm 0.02$ & $41.3 \mathrm{~b} \pm 1.6$ & $61.2 \mathrm{a} \pm 1.1$ & $60.7 \mathrm{a} \pm 1.1$ & $8.5 \mathrm{~ns} \pm 1.1$ \\
& CPM & $15.38 \mathrm{a} \pm 0.15$ & $0.48 \mathrm{~b} \pm 0.02$ & $41.1 \mathrm{~b} \pm 0.7$ & $60.9 \mathrm{a} \pm 1.6$ & $60.1 \mathrm{a} \pm 1.7$ & $9.1 \mathrm{~ns} \pm 2.2$ \\
\hline
\end{tabular}

Mean values \pm standard deviations. $C I=$ colour intensity, $L^{*}=$ brightness, $C^{*}=$ chromaticity, $a^{*}=$ redness, $b^{*}=$ yellowness. Values with the same letter in the same column and in the same variety mean that there are no statistically significant differences according to a Tukey test $(\mathrm{p}<0.05)$.

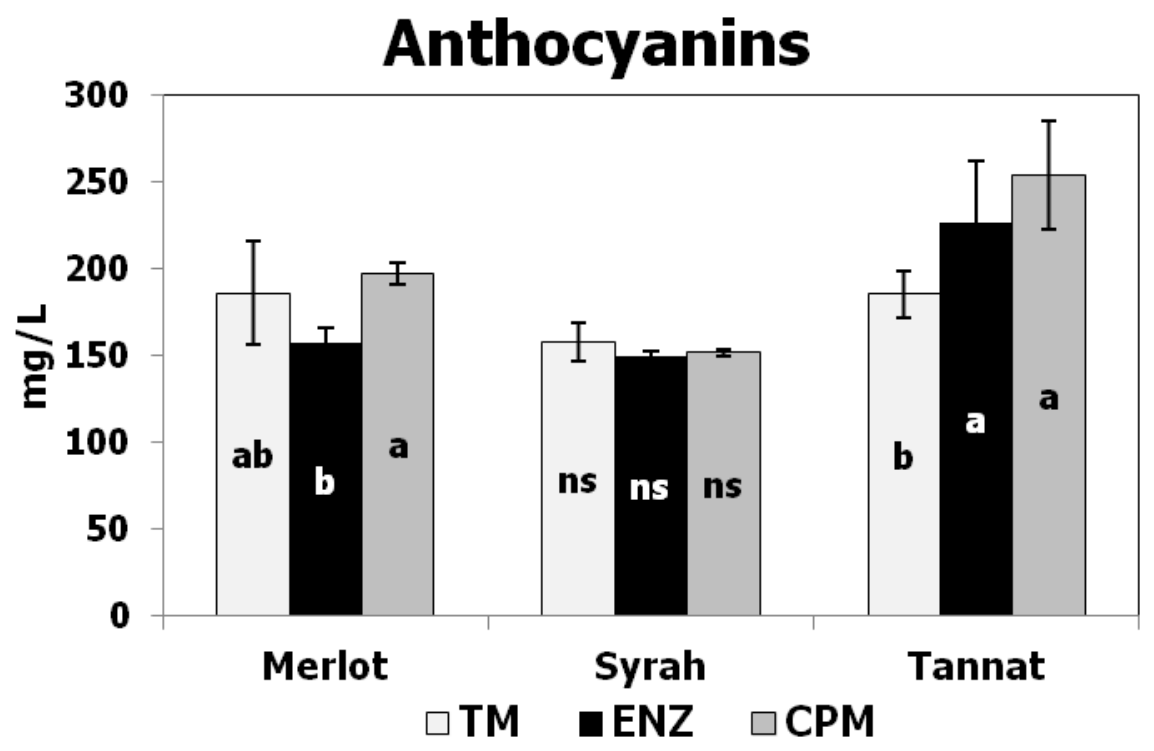

FIGURE 1

Anthocyanin contents of the wines of the three varieties elaborated by each winemaking procedure. Mean values and standard deviations expressed in malvidin-3-glucoside $\mathrm{mg} / \mathrm{L}$. 
TABLE 4

Polyphenol indexes of wines.

\begin{tabular}{lllccccc}
\hline Variety & Winemaking & \multicolumn{1}{c}{ TP } & Proanth. & PTan & A & C & P \\
\hline \multirow{3}{*}{ Merlot } & TM & $1121 \mathrm{~b} \pm 28$ & $1715 \mathrm{~b} \pm 51$ & $45.0 \mathrm{~b} \pm 1.4$ & $2.7 \mathrm{~ns} \pm 0.1$ & $0.9 \mathrm{ab} \pm 0.1$ & $1.6 \mathrm{~b} \pm 0.1$ \\
& ENZ & $1166 \mathrm{~b} \pm 32$ & $1754 \mathrm{~b} \pm 18$ & $47.0 \mathrm{~b} \pm 0.1$ & $2.7 \mathrm{~ns} \pm 0.1$ & $0.8 \mathrm{~b} \pm 0.1$ & $1.9 \mathrm{a} \pm 0.1$ \\
& CPM & $1361 \mathrm{a} \pm 104$ & $2189 \mathrm{a} \pm 58$ & $50.6 \mathrm{a} \pm 1.4$ & $2.8 \mathrm{~ns} \pm 0.2$ & $1.2 \mathrm{a} \pm 0.1$ & $1.7 \mathrm{~b} \pm 0.1$ \\
\hline \multirow{5}{*}{ Syrah } & TM & $810 \mathrm{~b} \pm 38$ & $1126 \mathrm{~ns} \pm 85$ & $37.3 \mathrm{~b} \pm 7.1$ & $1.6 \mathrm{~b} \pm 0.2$ & $0.8 \mathrm{~ns} \pm 0.2$ & $0.9 \mathrm{~b} \pm 0.2$ \\
& ENZ & $921 \mathrm{a} \pm 76$ & $1242 \mathrm{~ns} \pm 85$ & $39.4 \mathrm{a} \pm 1.0$ & $1.8 \mathrm{a} \pm 0.1$ & $0.9 \mathrm{~ns} \pm 0.2$ & $1.4 \mathrm{a} \pm 0.3$ \\
& CPM & $838 \mathrm{ab} \pm 30$ & $1131 \mathrm{~ns} \pm 157$ & $39.0 \mathrm{c} \pm 7.7$ & $1.7 \mathrm{ab} \pm 0.1$ & $0.8 \mathrm{~ns} \pm 0.1$ & $1.0 \mathrm{~b} \pm 0.1$ \\
\hline \multirow{3}{*}{ Tannat } & TM & $1119 \mathrm{~ns} \pm 157$ & $2005 \mathrm{~b} \pm 275$ & $32.6 \mathrm{~b} \pm 1.1$ & $2.6 \mathrm{~b} \pm 0.27$ & $1.6 \mathrm{c} \pm 0.1$ & $2.8 \mathrm{a} \pm 0.3$ \\
& ENZ & $1325 \mathrm{~ns} \pm 78$ & $2460 \mathrm{a} \pm 116$ & $35.1 \mathrm{a} \pm 0.3$ & $3.8 \mathrm{a} \pm 0.13$ & $2.1 \mathrm{~b} \pm 0.3$ & $2.6 \mathrm{ab} \pm 0.1$ \\
& CPM & $1264 \mathrm{~ns} \pm 112$ & $2281 \mathrm{ab} \pm 82$ & $35.1 \mathrm{a} \pm 0.8$ & $3.6 \mathrm{a} \pm 0.04$ & $2.7 \mathrm{a} \pm 0.3$ & $2.3 \mathrm{~b} \pm 0.2$ \\
\hline
\end{tabular}

Mean values \pm standard deviations. Values with the same letter in the same column and in the same variety mean that there are no statistically significant differences according to a Tukey test $(\mathrm{p}<0.05)$. Total polyphenol contents $(\mathrm{TP})$ are expressed in gallic acid $\mathrm{mg} / \mathrm{L}$; proanthocyanidin content (Proanth.) in cyanidin chloride $\mathrm{mg} / \mathrm{L}$. PTan $=$ tannin polymerisation index, $\mathrm{A}=$ colour due to anthocyanins, $\mathrm{C}=$ colour due to co-pigmentation, $\mathrm{P}=$ colour due to polymers.

varieties. Therefore, the behaviour of each grape variety in different years could be different (González-Neves et al., 2012).

Tannat wines had the highest levels of alcohol, total acidity, colour intensity, redness $\left(\mathrm{a}^{*}\right)$, anthocyanin and proanthocyanidin content, and the lowest luminosity (L*) and $\mathrm{pH}$ values (Tables 2-4; Fig. 1). These characteristics agree with those reported for this variety in previous works (González-Neves et al., 2006, 2009). In contrast, Syrah wines had the lowest alcohol and polyphenol content, colour intensity and redness, and the highest hue and luminosity (Tables 2-4; Fig. 1), which indicate that these wines had the least quality attributes. These results are related to the oenological potential of the Syrah grapes, which had less sugars and polyphenols than the others grapes (Table 1).

Winemaking practices exerted little influence on the basic composition of the wines (Table 2). Nevertheless, the different alternatives of winemaking modify the colour, polyphenolic and volatile composition of wines (Tables 3-5; Fig. 1). At devatting, the fermentation process was finished in the Merlot and Syrah wines. In contrast, alcoholic fermentation was much slower in Tannat; the density of these musts at devatting was 1020 to 1040 (data not shown), indicating that this process was not complete. The differences in the temperatures of the musts and in the alcohol concentration along maceration may have modified the extraction of polyphenols from the grapes of each variety (Canals et al., 2005).

The CPM established increases in the colour intensity and the content of total polyphenols, anthocyanins and proanthocyanidins in the Tannat and Merlot wines (Tables 3 and 4; Fig. 1). Similar results concerning anthocyanin release were reported for different grape varieties in several papers (Parenti et al., 2004; De Beer et al., 2006; Álvarez et al., 2009; Gil-Muñoz et al., 2009; Busse-Valverde et al., 2011). However, this practice had no effect on the colour intensity of Syrah wines, in disagreement with the results reported by Gómez-Míguez et al. (2007) and Heredia et al. (2010) for this variety. The colour of red wines was enhanced by cold pre-fermentative maceration in numerous studies (De Beer et al., 2006; Gómez-Míguez et al., 2007; Gil-Muñoz et al., 2009; Heredia et al., 2010), but the effect was not significant in others (Álvarez et al., 2009), although in these cases it was hoped that it would increase colour stability (Álvarez et al., 2009).

The different behaviour of the three varieties could be related to the differences in grape composition. The very high values of EA\% of Syrah (Table 1) lead to difficulties in the extraction of anthocyanins from the grape skins, which could explain the low effectiveness of CPM in this variety. Several authors stated that the effect of the cold pre-fermentative maceration depends on the degree of maturity reached by the grape and also on the variety, because these factors influence the phenolic composition and the ease with which the skin cell wall of the grape can be broken (González-Neves et al., 2012; Ortega-Heras et al., 2012).

CPM enhanced the colour due to anthocyanins, especially in Tannat. This practice enhanced the colour due to co-pigmentation in Merlot and especially in Tannat (Table 3). Many authors have signalled that the links between co-pigments are the first step in the reactions that produce new and more stable pigments (Boulton, 2001). Thus, this practice may contribute to the stabilisation of the colour in Merlot and Tannat wines.

Proanthocyanidin content was enhanced by CPM in Merlot $(27.6 \%)$ and in Tannat $(13.7 \%)$ in comparison to the control wines. However, this treatment had no effect on the proanthocyanidin levels of Syrah wines, in agreement with the findings of Busse-Valverde et al. (2010). In previous works it was reported that the improvement of tannin levels was the principal effect of CPM in Tannat wines (González-Neves et al., 2009). Nevertheless, differences in the winemaking conditions and principally in the duration of skin contact could explain the smaller impact on these compounds verified in the present work.

Winemaking modified the size of proanthocyanidins in the Syrah and Tannat wines, where the values of the tannin polymerisation index showed that the tannin molecules of ENZ and CPM wines were less polymerised than those of the control wines. Also, the average values of TPI were higher 
TABLE 5

Composition of major volatiles in wines.

\begin{tabular}{|c|c|c|c|c|c|c|c|}
\hline Variety & Winemaking & Ethyl acetate & Methanol & 1-propanol & $\begin{array}{c}\text { 2-methyl-1- } \\
\text { propanol }\end{array}$ & $\begin{array}{c}2 \text { and } \\
\text { 3-methyl-1- } \\
\text { butanol }\end{array}$ & $\begin{array}{c}\text { Total higher } \\
\text { alcohols }\end{array}$ \\
\hline \multirow{3}{*}{ Merlot } & $\mathrm{TM}$ & $25.2 \mathrm{~b} \pm 0.6$ & $145.1 \mathrm{c} \pm 8.3$ & $34.9 \mathrm{a} \pm 2.0$ & $55.1 \mathrm{~b} \pm 1.5$ & $369.0 \mathrm{~b} \pm 15.1$ & $459.0 \mathrm{~b} \pm 14.6$ \\
\hline & ENZ & $26.8 \mathrm{a} \pm 0.3$ & $225.3 \mathrm{a} \pm 1.1$ & $37.1 \mathrm{a} \pm 1.1$ & $52.4 \mathrm{c} \pm 1.0$ & $367.3 b \pm 4.3$ & $456.7 b \pm 6.4$ \\
\hline & CPM & $26.8 \mathrm{a} \pm 0.6$ & $155.2 b \pm 1.9$ & $21.25 b \pm 0.2$ & $99.8 \mathrm{a} \pm 1.8$ & $550.1 \mathrm{a} \pm 0.8$ & $671.1 \mathrm{a} \pm 2.0$ \\
\hline \multirow{3}{*}{ Syrah } & $\mathrm{TM}$ & $23.4 \mathrm{~ns} \pm 0.3$ & $120.0 b \pm 4.4$ & $32.6 \mathrm{~ns} \pm 5.0$ & $52.8 \mathrm{~b} \pm 1.1$ & $271.9 \mathrm{~ns} \pm 13.8$ & $357.4 \mathrm{~ns} \pm 7.8$ \\
\hline & ENZ & $23.3 \mathrm{~ns} \pm 0.7$ & $215.6 \mathrm{a} \pm 3.4$ & $30.9 \mathrm{~ns} \pm 2.9$ & $50.6 \mathrm{c} \pm 1.6$ & $276.0 \mathrm{~ns} \pm 2.2$ & $357.4 \mathrm{~ns} \pm 2.6$ \\
\hline & CPM & $22.8 \mathrm{~ns} \pm 1.8$ & $112.0 \mathrm{c} \pm 3.8$ & $31.7 \mathrm{~ns} \pm 0.1$ & $55.2 \mathrm{a} \pm 0.3$ & $279.3 \mathrm{~ns} \pm 2.2$ & $366.3 \mathrm{~ns} \pm 2.2$ \\
\hline \multirow{3}{*}{ Tannat } & TM & $34.3 b \pm 0.6$ & $59.1 b \pm 4.8$ & $30.1 b \pm 3.9$ & $42.8 b \pm 0.2$ & $283.0 b \pm 5.0$ & $355.9 \mathrm{~b} \pm 9.0$ \\
\hline & ENZ & $32.4 b \pm 2.4$ & $151.8 \mathrm{a} \pm 2.3$ & $22.6 \mathrm{a} \pm 2.0$ & $39.8 \mathrm{~b} \pm 0.7$ & $272.9 b \pm 5.2$ & $335.4 b \pm 2.7$ \\
\hline & CPM & $41.2 \mathrm{a} \pm 2.7$ & $55.6 \mathrm{~b} \pm 10.0$ & $48.9 \mathrm{c} \pm 1.0$ & $48.0 \mathrm{a} \pm 4.2$ & $316.1 \mathrm{a} \pm 11.7$ & $413.1 \mathrm{a} \pm 16.9$ \\
\hline
\end{tabular}

Mean values \pm standard deviations. Values with the same letter in the same column and in the same variety mean that there are no statistically significant differences according to a Tukey test $(\mathrm{p}<0.05)$. All compounds were expressed in $\mathrm{mg} / \mathrm{L}$.

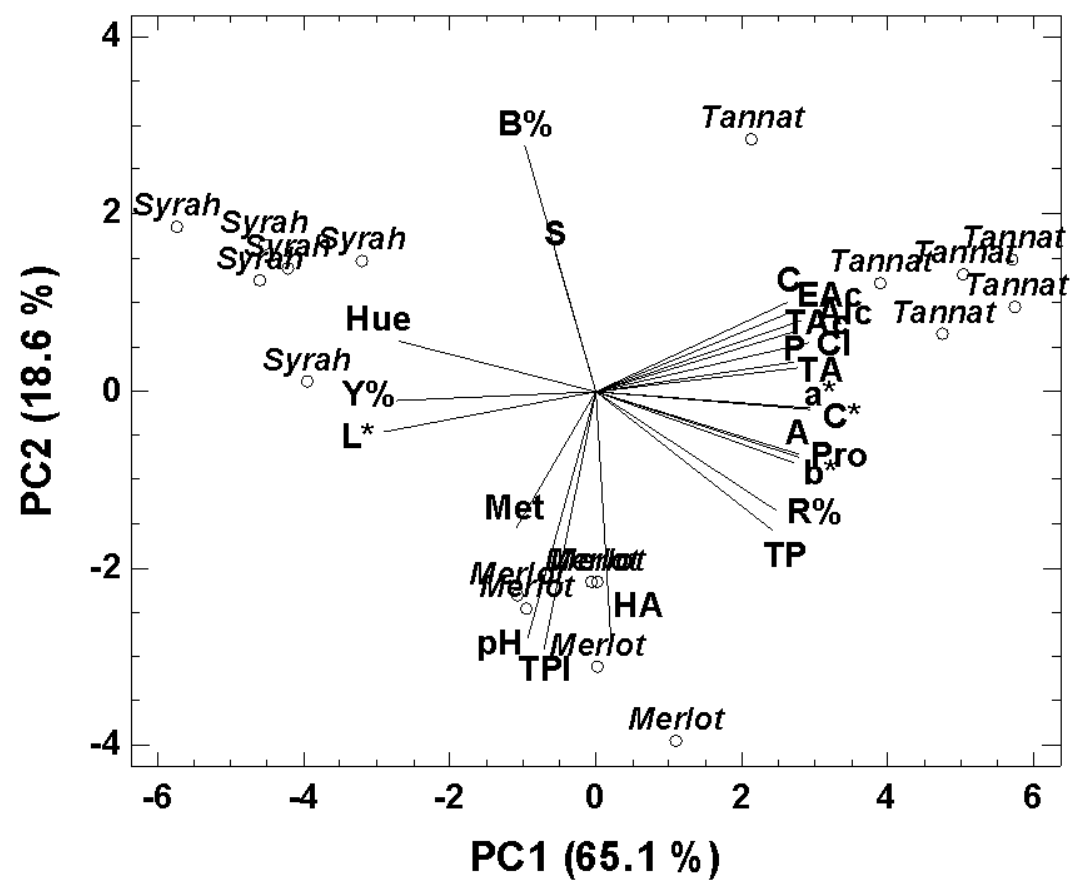

FIGURE 2

Biplot of the two first principal components obtained from the basic composition, volatile compounds, colour and phenolic composition of the wines. The variables included were ethanol content (Alc), titratable acidity (TAc), $\mathrm{pH}$ values ( $\mathrm{pH}$ ), residual sugar content (S), total higher alcohols (HA), ethyl acetate (EAc), methanol level (Met), colour intensity (CI), hue (Hue), proportion of yellow colour $(\mathrm{Y} \%)$, proportion of red colour $(\mathrm{R} \%)$, proportion of blue colour $(\mathrm{B} \%)$, brightness $(\mathrm{L} *)$, chromaticity $\left(\mathrm{C}^{*}\right)$, redness $\left(\mathrm{a}^{*}\right)$, yellowness $\left(\mathrm{b}^{*}\right)$, colour due to co-pigmentation $(\mathrm{C})$, colour due to anthocyanins $(\mathrm{A})$, colour due to polymers (P), total polyphenols (TP), proanthocyanidins (Pro), total anthocyanin content (TA), and tannin polymerisation index (TPI).

in the CPM wines of Merlot, although without significant differences from the respective control wines. The results are consistent with the fact that this procedure may contribute to the release of tannins of low molecular weight from the skin (Sacchi et al., 2005).

Overall, the results of our work are in agreement with several authors who have indicated that the effectiveness of CPM is strongly conditioned by the grape variety, because the composition of the skin cell walls could modify the release of their components during winemaking (OrtegaHeras et al., 2012; Ortega-Regules et al., 2012). Other authors have suggested that the effect of this technique is related to the ripeness of the grapes; the best results were obtained using grapes with low richness in anthocyanins (Reynolds et al., 2001; Álvarez et al., 2006). In contrast, Ortega-Heras et al. (2012) found that cold pre-fermentative maceration enhanced the release of pigments and colour stabilisation when the grapes reached a high degree of 
maturity. Furthermore, the results of previous works confirm that others characteristics of the grape, such as the size of the berry or the extractability of anthocyanins, could modify the effectiveness of CPM (González-Neves et al., 2012).

Pectolytic additions enhanced colour intensity and red colour, and decreased the luminosity of the wines of all varieties (Table 3). The principal impact on the colour was observed in Syrah, where the colour intensity of the ENZ wines was increased $19.0 \%$ in relation to the control. This effect was also significant in the Merlot $(+13.0 \%)$ and Tannat wines $(+11.2 \%)$. Several papers have shown positive effects of pectolytic enzymes on the colour of wine as a result of increases in the extraction of anthocyanins and tannins during winemaking (Romero-Cascales et al., 2008; Ortega-Heras et al., 2012; Romero-Cascales et al., 2012). However, in our study this oenological practice gave higher anthocyanin levels only in the wines of Tannat (Fig. 1).

ENZ enhanced the colour due to anthocyanins in Syrah, and especially in Tannat. In addition, ENZ enhanced the colour due to polymeric pigments in Merlot and especially in Syrah (Table 4).

Enzyme additions enhanced the proanthocyanidin content in all the wines, although the differences in relation to the control were statistically significant only in Tannat wines (Table 5). Many authors indicate that the improvement in the proanthocyanidin content of wines produced with commercial macerating enzymes is due to the extraction of tannins from the skin, as well as the release of tannins from seeds (Busse-Valverde et al., 2010, 2011; Bautista-Ortin et al., 2012). The increase in proanthocyanidin content due to the enzymatic preparations in relation to the control wines was $2.2 \%$ in Merlot, $10.3 \%$ in Syrah and $22.7 \%$ in Tannat. Several authors have also indicated that the effectiveness of maceration enzymes differs according to grape variety, as it is related to the structure and composition of the skin cell walls and the seed cell walls (Ortega-Regules et al., 2008; Bautista-Ortin et al., 2012).

The volatile composition of the wines was modified by winemaking (Table 5). The content of ethyl acetate was increased by cold soaking in Tannat, in agreement with Salinas et al. (2003). The content of higher alcohols was increased by CPM in the Tannat and particularly in the Merlot wines. The main differences were verified in the levels of 2-methyl1-propanol and 2- and 3-methyl-1-butanol (Table 5). These results could be related to the development of nonSaccharomyces yeast strains during cold maceration. Aroma modifications induced by these yeasts may contribute to the quality enhancement and improved complexity of wines elaborated by using CPM (Zott et al., 2008). Nevertheless, the levels of higher alcohols in the Merlot wines could be related to undesirable aromas (Louw et al., 2010).

Moreover, the different effects of CPM on the production of these compounds in each variety may be related to the levels of their precursors. Louw et al. (2010) signalled that the cultivar is the principal factor related to the production of higher alcohols. It was suggested that the amino acid profiles of grapes contribute significantly to the aroma differences between the wines of different varieties. Furthermore, CPM could enhance the levels of amino acids in the must because these compounds are water soluble and their content is dependent on the length of time that the skins are macerated in the must (Callejón et al., 2010).

Pectolytic enzyme levels significantly increased the methanol levels of wines (Table 5). These results are consistent with those reported by several authors (Revilla \& González-Sanjosé, 1998; Cabaroglu, 2005; Romero-Cascales et al., 2012) who indicated that commercial enzymes have pectin methyl esterase activity that catalyses the cleavage of methyl groups. Nonetheless, the amounts of this compound (Table 5) are far within maximum acceptable limits.

Principal component analysis (PCA) applied by using the composition and colour of the wines was able to identify similarities among wines from the same variety. Fig. 2 shows that the effect of the composition of the grapes, related to berry ripeness and variety, prevails over the effect of the winemaking procedure. The two first components explained $83.7 \%$ of the total variance. The distribution of the sample scores in the biplot generated by the first two components shows that the first eigenvector (PC1) separates the wines from the three varieties. The positive values of this principal component were related to the Tannat samples and positively correlated with the phenolic content (total polyphenols, anthocyanins and proanthocyanidins), chromatic indexes (colour intensity, redness and co-pigmentation), and alcohol, total acidity and ethyl acetate content. The negative values of the first component were related to the Syrah samples and principally correlated negatively with luminosity, yellow percentage and hue. The second eigenvector (PC2) essentially separates the Merlot samples than the others wines. They could be characterised by the tannin polymerisation index, content of higher alcohols and $\mathrm{pH}$ values.

Principal component determination (PCA) also is a statistical tool often used in data reduction to identify a small number of factors that explain most of the variance observed in a much larger number of manifest variables (Arvanitoyannis et al., 1999). In our case, several variables had a redundant effect on the description of wines because they were involved in very high correlations among them. Colour intensity $(\mathrm{CI})$, redness $\left(\mathrm{a}^{*}\right)$, colour due to anthocyanins (A), luminosity $\left(\mathrm{L}^{*}\right)$, blue colour proportion $(\mathrm{B} \%)$, proanthocyanidin content (Pro), tannin polymerisation index (TPI), alcohol levels (Alc), total acidity (TAc) and higher alcohols content (HA) were the variables that had the highest coefficients in the two first principal components. Therefore, colour, tannins, major base components and major volatile compounds made the most important contribution to the characterisation of the wines analysed.

\section{CONCLUSIONS}

The colour and polyphenolic composition of the wines of the three varieties differed considerably. Tannat wines had the highest colour intensity, redness $\left(\mathrm{a}^{*}\right)$, anthocyanin and proanthocyanidin content, and the lowest luminosity ( $\left.\mathrm{L}^{*}\right)$. These characteristics agree with the oenological potential previously reported for this variety. In addition, the results were related to the fact that the grade of ripeness of the grapes of the three varieties was different.

Winemaking practices exerted little influence on the basic composition of the wines, but they significantly modified the colour, polyphenolic and volatile composition 
of the wines.

The CPM increased colour intensity and the contents of total polyphenols, anthocyanins and proanthocyanidins in the Tannat and Merlot wines. Moreover, this practice enhanced the colour due to anthocyanins in Syrah and Tannat, and the colour due to co-pigmentation in Merlot and Tannat.

Enzyme additions enhanced colour intensity and red colour and decreased luminosity in all the wines. This practice enhanced the colour due to anthocyanins in Syrah and Tannat, and the colour due to polymeric pigments in Merlot and Syrah. Enzyme additions enhanced the proanthocyanidin content in all cases.

Pectolytic enzymes significantly increased the methanol levels of the wines. However, the amounts of this compound were far within maximum acceptable limits.

Multivariate analysis of the data showed significant separation between the wines of each variety, since the colour and composition were largely related to the cultivar and berry ripeness, independent of winemaking procedures.

\section{LITERATURE CITED}

Álvarez, I., Aleixandre, J.L., García, M.J. \& Lizama, V., 2006. Impact of prefermentative maceration on the phenolic and volatile compounds in Monastrell red wines. Anal. Chim. Acta 563, 109-115.

Álvarez, I., Aleixandre, J.L., García, M.J., Lizama, V. \& Aleixandre, J., 2009. Effect of the prefermentative addition of co-pigments on the polyphenolic composition of Tempranillo wines after malolactic fermentation. Eur. Food Res. Technol. 228, 501-510.

Arvanitoyannis, I., Katsota, M., Psarra, E., Soufleros, E. \& Kallithraka, S., 1999. Application of quality control methods for assessing wine authenticity: use of multivariate analysis (chemometrics). Trends Food Sci. Technol. 10, 321-336.

Ayala, F., Echávarri, J.F. \& Negueruela, A.I., 1997. A new simplified method for measuring the color of wines. I. Red and rosé wines. Am. J. Enol. Vitic. 48(3), 357-363.

Bautista-Ortín, A., Jiménez-Pascual, E., Busse-Valverde, N., López-Roca, J., Ros-García, J. \& Gómez-Plaza, E., 2012. Effect of wine maceration enzymes on the extraction of grape seed proanthocyanidins. Food Bioprocess Technol. 10.1007/s11947-011-0768-3.

Bautista-Ortín, A., Martínez-Cutillas, A., Ros-García, J., López-Roca, J. \& Gómez-Plaza, E., 2005. Improving colour extraction and stability in red wines: the use of maceration enzymes and enological tannins. Int. J. Food Sci. Technol. 40, 867-878.

Boulton, R., 2001. The copigmentation of anthocyanins and its role in the color of red wine: a critical review. Am. J. Enol. Vitic. 52(2), 67-87.

Busse-Valverde, N., Gómez-Plaza, E., López-Roca, J., Gil-Muñoz, R. \& Bautista-Ortín, A., 2011. The extraction of anthocyanins and proanthocyanidins from grapes to wine during fermentative maceration is affected by the enological technique. J. Agric. Food Chem. 59, 5450-5455.

Busse-Valverde, N., Gómez-Plaza, E., López-Roca, J., Gil-Muñoz, R., Fernández-Fernández, J. \& Bautista-Ortín, A., 2010. Effect of different enological practices on skin and seed proanthocyanidins in three varietal wines. J. Agric. Food Chem. 58, 11333-11339.

Cabaroglu, T., 2005. Methanol contents of Turkish varietal wines and effect of processing. Food Control, 16, 177-181.

Callejón, R., Troncoso, A. \& Morales, M., 2010. Determination of amino acids in grape-derived products: a review. Talanta, 81, 1143-1152.
Canals, R., Llaudy, M., Valls, J., Canals, J. \& Zamora, F., 2005. Influence of ethanol concentration on the extraction of color and phenolic compounds from the skin and seeds of Tempranillo grapes at different stages of ripening. J. Agric. Food Chem. 53, 4019-4025.

De Beer, D., Joubert, E., Marais, J. \& Manley, M., 2006. Maceration before and during fermentation: effect on Pinotage wine phenolic composition, total antioxidant capacity and objective colour parameters. S. Afr. J. Enol. Vitic. 27, 137-150.

Gil-Muñoz, R., Moreno-Pérez, A., Vila-López, R., Fernández-Fernández, J., Martínez-Cutillas, A. \& Gómez-Plaza, E., 2009. Influence of low temperature prefermentative techniques on chromatic and phenolic characteristics of Syrah and Cabernet Sauvignon wines. Eur. Food Res. Technol. 228, 777-788

Glories, Y., 1984. La couleur des vins rouges. 2e. Partie: Mesure, origine et interpretation. Conn. Vigne Vin 18(4), 253-271.

Glories, Y. \& Augustin, M., 1993. Maturité phénolique du raisin, conséquences technologiques: application aux millésimes 1991 et 1992. In C R Coll. J. Techn. CIVB, Bordeaux. pp. 56-61.

Gómez-Míguez, M., González-Miret, G.L. \& Heredia, F.J., 2007. Evolution of colour and anthocyanin composition of Syrah wines elaborated with prefermentative cold maceration. J. Food Eng. 9, 271-278.

González-Neves, G., Franco, J., Moutounet, M. \& Carbonneau, A., 2006. Différenciation des vins de Tannat, Merlot et Cabernet-Sauvignon de 1'Uruguay selon leur composition polyphénolique globale. J. Int. Sci. Vigne Vin 40(2), 81-89.

González-Neves, G., Gil, G., Barreiro, L., Berriel, V. \& Favre, G., 2009. Incidencia de distintas técnicas de vinificación sobre el color y los contenidos de pigmentos de vinos tintos jóvenes Tannat. Proc. $32^{\circ}$ World Congress of Wine and Vine, Zagreb.

González-Neves, G., Gil, G., Barreiro, L., Bochicchio, R., Gatto, G., Tessore, A. \& Favre, G., 2010. Pigment profile of red wines cv. Tannat made with alternative winemaking. J. Food Comp. Anal. 23(5), 447-454.

González-Neves, G., Gil, G., Favre, G. \& Ferrer, M., 2012. Influence of grape composition and winemaking on the anthocyanin composition of red wines of Tannat. Int. J. Food Sci. Technol. 47, 900-909.

Heredia, F., Escudero, M., Hernandez, D., Gordillo, B., Meléndez, A., Vicario, I. \& González, M., 2010. Influence of the refrigeration technique on the colour and phenolic composition of Syrah red wines obtained by prefermentative cold maceration. Food Chem. 118(2), 377-383.

Louw, L., Tredoux, A., Van Rensburg, P., Kidd, M., Naes, T. \& Nieuwoudt, H., 2010. Fermentation-derived aroma compounds in varietal young wines from South Africa. S. Afr. J. Enol. Vitic. 31(2), 213-225.

O.I.V., 2012. Recueil des méthodes internationales d'analyse des vins et des moûts. Vol. 1. Org. Int. Vigne Vin., Paris.

Ortega-Heras, M., Pérez-Magariño, S. \& González-Sanjosé, M., 2012. Comparative study of the use of maceration enzymes and cold prefermentative maceration on phenolic and anthocyanic composition and colour of a Mencía red wine. LWT - Food Sci. Technol. 48, 1-8.

Ortega-Regules, A., Ros-García, J., Bautista-Ortín, A., López-Roca, J. \& Gómez-Plaza, E., 2008. Changes in skin cell wall composition during the maturation of four premium wine grape varieties. J. Sci. Food Agric. 88, 420-428.

Parenti, A., Spugnoli, P., Calamai, L., Ferrari, S. \& Gori, C., 2004. Effects of cold maceration on red wine quality from Tuscan Sangiovese grape. Eur. Food Res. Technol. 218, 360-366.

Revilla, I. \& González-SanJosé, M., 1998. Methanol release during fermentation of red grapes treated with pectolytic enzymes. Food Chem. 63(3), 307-312. 
Revilla, I. \& González-SanJosé, M., 2001. Evolution during the storage of red wines treated with pectolytic enzymes: new anthocyanin pigment formation. J. Wine Res. 12(3), 183-197.

Revilla, I., Pérez-Magariño, S., González-Sanjosé, M. \& Beltrán, S., 1999. Identification of anthocyanin derivatives in grape skin extracts and red wines by liquid chromatography with diode array and mass spectrometric detection. J. Chrom. A, 847, 83-90.

Reynolds, A., Cliff, M., Girard, B. \& Kopp, T., 2001. Influence of fermentation temperature on composition and sensory properties of Semillon and Shiraz wines. Am. J. Enol. Vitic. 52(3), 235-240.

Ribéreau-Gayon, P. \& Stonestreet, E., 1966. Dosage des tanins dans du vin rouge et détermination de leur structure. Chim. Anal. 48, 188-196.

Romero-Cascales, I., Fernández-Fernández, J., Ros-García, J., López-Roca, J. \& Gómez-Plaza, E., 2008. Characterisation of the main enzymatyic activities present in six commercial macerating enzymes and their effects on extracting colour during winemaking of Monastrell grapes. Int. J. Food Sci. Technol. 43, 1295-1305.

Romero-Cascales, I., Ros-García, J.., López-Roca, J. \& Gómez-Plaza, E., 2012. The effect of a commercial pectolytic enzyme on grape skin cell wall and colour evolution during the maceration process. Food Chem. 130, 626631
Sacchi, K., Bisson, L. \& Adams D., 2005. A review of the effect of winemaking techniques on phenolic extraction in red wines. Am. J. Enol. Vitic. 56(3), 197-206.

Salinas, R., Garijo, J., Pardo, F., Zalacain, A. \& Alonso, G., 2003. Color, polyphenol, and aroma compounds in rosé wines after prefermentative maceration and enzymatic treatments. Am. J. Enol. Vitic. 54(3), 195-202.

Singleton, V. \& Rossi, J., 1965. Colorimetry of total phenolics with phosphomolybdic and phosphotungstic acid reagents. Am. J. Enol. Vitic. $16,144-158$.

Vivas, N., Glories, Y., Lagune, L., Saucier, C. \& Augustin, M., (1994). Estimation du degré de polymérisation des procyanidines du raisin et du vin par la méthode au p-diméthylaminocinnamaldéhyde. J. Int. Sci. Vigne Vin 28(4), 319-336.7

Zott, K., Miot-Sertier, C., Claisse, O. \& Lonvaud-Funel, A., 2008. Dynamics and diversity of non-Saccharomyces yeasts during the early stages in winemaking. Int. J. Food Microb. 125, 197-203. 